\title{
Current State of Knowledge of the Development of Early Modern Ceramics in the Czech Republic
}

\section{Gabriela Blažková $a$}

\begin{abstract}
This study is an overview of the professional interest in archaeology of the modern age in the Czech Republic. Increased interest in the archaeology of the Modern period came after the year 2000. The number of published Early Modern pottery assemblages has increased significantly over the past decade. Recent years have seen a change in the publication strategy of Modern period assemblages. As such, the large Modern period find inventory is forcing archaeology to make a critical selection of assemblages which will subsequently be the subject of detailed processing and evaluation. The most important selection criteria include the complexity of the find situation, the possibility of placing it into the social context or the actual expansion of knowledge of period material culture.
\end{abstract}

KEYWORDS: Czech Republic, Early Modern period, ceramics, chronology, stove tiles, conference

\section{INTRODUCTION}

The first definition of post-medieval - Early Modern period - archaeology in Czech Republic was advanced by Z. Smetánka and J. Žegklitz (1989: 728; Smetánka and Žegklitz 1990: 7), who stated that post-medieval archaeology involved the period between the turn of the I6th century and the end of the I8th century. Based on the study of pottery from Prague, Pavel Vařeka established the transition from late medieval to Early Modern pottery in the period between the turn of the i6th century up to the middle of the I6th century (most recently Vařeka 20I3: 8, 9). In general, this was the period marked by the disappearance of late medieval traditions and the emergence of Early Modern innovations. From a historical perspective, this was the

a Institute of Archaeology of the Czech Academy of Sciences, Prague, Letenská 4, II8 or Prague I, Czech Republic; e-mail: blazkova@arup.cas.cz; https://orcid.org/0000-0002-0025-0902 
I26 | Gabriela Blažková

Renaissance period in Bohemia and Moravia. ${ }^{1}$ The widely accepted dividing line between the Early Modern and Modern periods is the mid-17th century, a boundary that was established on the basis of the widespread social changes that occurred in society following the Thirty Years' War (I6I8-1648), the consolidation of Habsburg power and from the perspective of the cultural ascent of the Baroque. Although this is a building style, there is a noticeable change in the taste of the inhabitants and in the objects of common daily use, i.e., the "Baroque-isation" of pottery and glass forms and the method of decoration. The period of $1800-1900$, referred to as the Industrial Age typically focuses on monuments associated with the Industrial Revolution. It is characterised by the emergence, and especially the spread, of ceramic materials such as creamware and porcelain and the massive production of stoneware mainly as packaging for mineral water. The Industrial Revolution in general led to an increase in ceramic production. In recent years, the archaeology of the Modern past - contemporary archaeology (Tab. I) - has developed very successfully with a focus on the research of not only threatened, but often also non-endangered sites (Krajíc et al., 20I7: 374).

Over the past 15 years, several authors have tried to describe and evaluate the development of Modern period archaeology; the earliest summary was compiled by Rudolf Krajíc (2007). The state of research in the field of Modern period archaeology was evaluated by the author of this study in her dissertation (Blažková 20II: 6-15), which became the foundation of a subsequent publication (Blažková 20I3: 183-186) and, simultaneously, inspiration for the study by J. Žegklitz (20I3). An updated overview of the state of research of Modern archaeology in the Czech Republic was published in connection with the international Archaeologia historica conference. In all these studies, the beginnings and subsequent development of Modern archaeology in the Czech Republic are described in varying degrees of detail, ${ }^{2}$ which can be marked in terms of methodological approach to historical archaeology. ${ }^{3}$ At the same

Historical research also divides the Modern period into two stages: the term "Early Modern period" is used for the period of I500-I650, the "Modern period" for I650-1790/1800 (Petrán et al., I995: 31). The beginning of the Early Modern period then approximately overlaps with the beginning of the Renaissance (Bůžek et al., 2007: 44).

2 The scope of this text is limited by the space available. For this reason, citations are restricted mainly to works published in the last six years and the comprehensive studies containing more extensive bibliographies and which were of fundamental importance for the constitution of the archaeology of the Modern period. These publications can be used to supplement the information and especially the links to earlier publications.

3 Historical archaeology has a quite clear conceptualisation in the United States and Great Britain. Many definitions set different priorities, there is basically agreement that historical archaeology begins with the modern era, or with the European global expansion. Besides this chronological approach, it also incorporates information from written records, pictorial sources, and oral history. Historical archaeology is therefore predicated on this interdisciplinarity between archaeology, the study of written and pictorial sources, oral history, and anthropology (Mehler 2013: I8). 
time, it should be mentioned that no study has yet been published that would deal in detail with the integration of Czech post-medieval and modern archaeology into a theoretical framework. ${ }^{4}$

\section{POST-MEDIEVAL ARCHAEOLOGY UP UNTIL 2000}

Early interest in Modern pottery finds can be connected with the architect Jiří Koula, who studied slipware. In his analysis of Prague finds, Koula showed extraordinary erudition and intuitively formulated working hypotheses (Koula 1917-1919), the validity of which was fully confirmed by later research. His contemporaries dealing with the issue of Modern ceramics were the museologist Kliment Čermák and the archaeologist Emanuel Leminger. The work of the potter and collector Heřman Landsfeld and the ethnographer and archaeologist Karel Černohorský are also important, especially for Moravia. A more broadly conceived interest in the post-medieval period is connected with the post-war development of medieval archaeology. Since the end of the 1960s, there was a gradual increase in published assemblages with a post-medieval theme, though these still could be numbered in the single digits. A key figure of this period was the archaeologist and ethnographer Vladimír Scheufler, who was the first to attempt to establish a border between the spheres of interest of archaeology and ethnography (Scheufler 1972). And yet, he did not use the term "Early Modern pottery". For Scheufler, the period between 1550 and 1650 was a transitional time between medieval and folk ceramics (Scheufler 1972: 13), or between folk and stylistic/non-folk ceramics. He also closely collaborated with the foreign archaeologists, ethnographers, pottery collectors and potters who, in 1968, founded the Internationales HafnereiSymposium (IHS), later renamed Arbeitskreis für Keramikforschung (AfK), ${ }^{5}$ and whose annual professional meetings he regularly attended, ending in the 1970s. As such, he was often the only representative from Czechoslovakia who had the opportunity to be in personal contact with colleagues and follow current research issues.

The analyses of the find assemblage from Strážnice by Jiří Pajer rank among the most heavily used works on Early Modern ceramics to this day (1982; 1983). Pajer later built on these analyses with his processing of Anabaptist faience from Strachotín (Pajer 200I) and he summarised the activities of Anabaptist potters in south Moravia in later publications (e.g., Pajer 2006; 2007).

For a attempts of conceptualization the origins, academic parameters, and practical fields of activity of historical archaeology in Central Europe, see Mehler 2013, Schreg 2013.

5 Arbeitskreis für Keramikforschung (AfK) continues to host professional symposia today (Okmhb.de 202I). The 52nd Internationales Keramik-Symposium was held in September 2019 in Bad Muskau, Germany. The 53rd annual symposium was cancelled in 2020 due to the COVID-I9 pandemic. 
I28 Gabriela Blažková

The Working Group for the Archaeology of the I6th-19th Century was established in the mid-1980s (Krajíc 2007: 58) and the outcome of their efforts was a seminar devoted to Modern period archaeology held in Beroun in 1986; one of the results of this seminar was the publication of presented contributions (Studies 1990). At the same time, the thematically focussed meeting was an impulse for a special publication of Modern period find assemblages (e.g., Frolík et al., 1988). Although the growth in construction activities and the overall change in the social climate in the 1990s marked the end of the working group's activities, this did not mean the complete end of publications of Early Modern pottery assemblages. One of the most important works from this period is the publication of a waste assemblage from the house of the beltmaker Prokop of Tábor (Krajíc 1998) and the full processing of material from several plots from medieval Most, including the Early Modern parts of the find assemblage (Klápště 2002).

\section{POST-MEDIEVAL ARCHAEOLOGY AFTER 2000}

Increased interest in the archaeology of the Modern period came after the year 2000, a fact undoubtedly related to the establishment of new departments and institutes of archaeology in several Czech universities (Opava, Plzeň, České Budějovice, Hradec Králové, Pardubice). Apparent at the beginning of this period is an effort to establish post-medieval archaeology as a fully-fledged archaeological discipline. Two basic facts surface in the published works: the first is an attempt to defend the significance of the publication of a given assemblage, while the second is the need to deal with the method of processing typically very large pottery assemblages, which, however, does not always lead to the desired goal (e.g., Marešová 200I). As such, significant space is devoted to the method of description and statistical evaluation of the assemblage (e.g., Dohnal and Koucký 2000; Dohnal et al., 200I; Dohnal and Vařeka 2002). Playing an important role during this period have been studies by the ethnographer Vítězslav Štajnochr (2004; 2005; 2006; 2007; 2008) on Modern pottery forms in terms of their functional use.

The number of published Early Modern pottery assemblages has increased significantly over the past decade, with an important role for an understanding of pottery production being played by assemblages from waste pits at Prague Castle (Blažkova and Vepřekova 20I5; Blažkova et al., 2016). A morphological analysis has made it possible to create a chronology of the development of Early Modern pottery in Prague (Blažková 2013; 20I8; Blažková and Žegklitz 20I6). These assemblages became the basis for the publication of Early Modern assemblages from various parts of the Czech Republic, not only in chronological but also methodological terms. One example is the publication of pottery production from south Bohemia (Čapek and Preusz 2019a). On the other hand, the publication of finds from northeast Bohemia does not deviate from the methodology applied in the first decade of the 2Ist century (Drnovský 20I8). 
However, unlike that decade, recent years have seen a change in the publication strategy of Modern period assemblages; these are typically from waste pits that have produced both reconstructable ceramic and glass vessels, the processing of which can expand existing knowledge of everyday material culture. As such, the large Modern period find inventory is forcing archaeology to make a critical selection of assemblages that will subsequently be the subject of detailed processing and evaluation. The most important selection criteria include the complexity of the find situation (Čapek and Militký et al., 2016), the possibility of placing it into the social context (Cymbalak and Matějková 20I2; Cymbalak et al., 20I9; Čiháková and Müller 20I3) or the actual expansion of knowledge of the material culture of the period (e.g., Matějková 20I7). ${ }^{6}$

The establishment of post-medieval archaeology has generated several sub-topics that are identical to issues being addressed across Europe, with one of these being the subject of slipware. In the Czech environment, this is mainly painted products from 1550 to 1630 that associated for many years with Beroun. ${ }^{7}$ Under the influence of the written records, certain finds of material culture were connected with Beroun by amateur archaeologist and architect Jan Koula as early as the beginning of the 2oth century (Koula 1917-1919, 250-257). Beroun pottery again received attention in the 1980s (Matoušek and Scheufler 1983; Matoušek et al., 1985; Žegklitz and Zavřel 1990). Thanks to new field research, this issue was reopened directly in Beroun (Vyšohlíd 20I5a), in Prague (Žegklitz 20I5) and, at the same time, in connection with the processing of finds from Prague Castle (Blažková 20I9). The Early Modern slipware from Bohemia corresponds to the European standards of this time, both from the perspective of ceramic forms and the method of decoration. It used double firing and not very hard-fired thicker body of red colour as for German Werraware (Stephan 1987: IOI; 1992; 20I2). Pottery forms include common kitchen ceramics and tableware, miniature vessels (toys) and objects primarily serving as decoration, such as bowls on an openwork foot. Beroun ware is similar to the finds of northern Germany style slipware (Gaimster 2006; Witte 2014), from Straubing in Bavaria (Enders 1982: 23, taf. 17/32; I990: taf. I5-I7; 2005: 32, 33, taf. 2.I, 2.2, 7.I), from Saxony (Krabath 20I2: 75-79).

In contrast, attention is newly being paid to the continued use of painted decoration in the second half of the 17th century (Matějková 2019). Another Europe-wide subject is the study of pipes, artefacts that have been the focus of the work of Martin Vyšohlíd in the Czech Republic for many years (Vyšohlíd 20II; 20I4; 2015b).

The growth of published collections has allowed archaeologists to pay close attention to specific types of ceramic production, including its integration into at least

6 That no references are provided to articles that were published in the anthologies of the Forum Archaeologiae Post-Mediaevalis conference is intentional (Studies 1990; 2007; 2009; 2012), as these publications are directly thematically focused on the issues of the Early Modern period.

7 Beroun is located roughly $40 \mathrm{~km}$ southwest of Prague. 
I30 | Gabriela Blažková

the Central European context. These are most often specific ceramic products with a clear use, i.e., distillation ceramics (Blažková et al., 202I), flowerpots (Matějková 20I2; 202I) or pottery kilns (Čapek and Preusz 2019b).

\section{STOVES TILES}

Stove tiles make up a distinct group of pottery finds; the terminology used to describe them was defined by Zdeněk Smetánka $(1968 ; 1969)$ and is used to this day. The 1980s and 90 are linked primarily to the work of Zdeněk Hazlbauer (1998), who, working with a wide range of archaeologists and museologists, attempted to map stove tile production from the Gothic period to the Baroque for the entire Czech Republic. Hazlbauer's work became the basis mainly for the processing of vast museum collections. ${ }^{8}$ Not only thanks to their attractive design, the Gothic and Renaissance stove tiles are a popular object of interest for archaeologists, both in museum collections and find assemblages. A detailed study of the design of the front heating wall with relief decoration makes it possible to create a relatively accurate chronological classification of specific tiles, even on the basis of the identification of the prints that served as their model. The scope of some studies goes beyond the prevailing narrow focus on typology or iconography and seeks to emphasise more generally conceived cultural and historical issues (e.g., Žegklitz et al., 2009; Žegklitz 20II; 20I2).

A summary of the current state of knowledge of stove tile production, including a high quality publication, was made possible by two thematic exhibitions devoted to tile production from the High Middle Ages to the Modern period. The first exhibition was held at the Regional Museum and Gallery in Most in the first half of 2018 (Šrejberová 20I7; 20I8). The outcome of the processing of the extensive find inventory from the rescue archaeological excavation on Republic Square in Prague by J. Žegklitz was the exhibition To Špaček for a Stove, held by the Museum of the Capital City of Prague and the company Archaia z.ú. from May 2019 to March 2020 (Žegklitz 2019).

\section{ARCHAEOMETRY}

Learning about ceramics from an archaeological perspective on the basis of macroscopic observations has its limits. Efforts have been made in recent years to solve this problem in cooperation with analytical chemists. In the case of selected assemblages, attention has been paid to analyses of the ceramic body, glazes and even the degradation of the

8 A comprehensive list of works dealing with the topic of Gothic and Renaissance stove tiles, including publications by Z. Hazlbauer, was most recently presented by J. Žegklitz (2019). 
pottery in connection with their deposition and the impacts of the surrounding environment. Today, many analytical methods common in material research are applied: for identifying the chemical and mineralogical composition, these are mainly X-ray methods (XRF, XRD) supplemented with microscopy (optical OM, electron SEM); still others are thermal analyses (DTA, TG, STA), spectroscopy of vibrational spectra (IR, RS) and Raman spectroscopy (e.g., Čapek et al., 2018; Kloužkova et al., 2020).

\section{CONFERENCE}

Communication and the sharing of experiences in the discipline are an integral part of professional work. The need for regularly organised personal meetings was the motivation behind the establishment of the Forum Archaeologiae Post-Mediaevalis international conference. The initiator and main organiser of this event was J. Žegklitz. A total of five conferences were held biannually starting in 2006, with the last event being held in 20I4. Three extensive anthologies of articles reflecting the current state of Early Modern research in Bohemia and beyond were published (Studies 2007; 2009; 2012). In 2016, the 48th Archaeologia Historica international conference on medieval archaeology, which was held in České Budějovice, was devoted to the issue of post-medieval archaeology (AH 2017). The need for regular meetings of scholars studying similar subjects led to the organisation of the international conference entitled EUROPA POSTMEDIAEVALIS 20I8, Post-Medieval Pottery Between (Its) Borders in Prague in 2018, followed by the publication of the presented articles (EP 2019). Although the second conference in 2020 could not be held due to the worldwide COVID-I9 pandemic, an anthology of articles was published in 202I (EP 202I).

\section{CONCLUSION}

More than a century has passed since the publication of Early Modern painted potsherds by J. Koula. Since then, hundreds of Modern ceramic assemblages and contexts have been published and a chronology of individual periods has been established. The increasing number of published assemblages has meant regular corrections in the dating of ceramic production and at the same time it is a prerequisite for larger comparative studies, which will compare ceramic production not only within a specific region, but between them. In cooperation with natural scientists, the range of addressed issues is constantly expanding and creates new topics of research. In general it can be said that Czech archaeology of the Modern period is today a firmly entrenched discipline and an integral part of European research and reflects a modern methodological approach of historical archaeology. 
Table 1. Chronology of archaeology of the Modern age in the Czech Republic.

\begin{tabular}{|l|l|}
\hline Early Modern Age & $1400 / 1500-1650$ \\
\hline Modern Age & $1650-1800$ \\
\hline Industrial Age & $1800-1900$ \\
\hline Contermporary Achaeology & after 1900 \\
\hline
\end{tabular}

\section{ACKNOWLEDGEMENTS}

This text was produced with support from the Czech Ministry of Culture NAKI II project - Technology of Treatment and Identification of Degradation Processes of Ceramic Finds from Hradčany Palaces - Methods of Restoration and Conservation of Porous and Dense Ceramics and Porcelain (NAKI II DGi8Po2OVVo28).

\section{REFERENCES:}

AH 2017. Archaeologia historica 42. Brno.

Blažková, G. 20II. Hmotná kultura Pražského hradu raného novověku ve svètle archeologických nálezů The material culture of Prague Castle in the Early Modern period in light of archaeological finds. Unpublished $\mathrm{PhD}$ thesis, Charles University Prague.

Blažková, G. 20I3. Vývoj raně novověké kuchyňské a stolní keramiky v Čechách na základě souborů z pražského hradu - The development of Early Modern ceramic kitchenware and tableware in Bohemia based on assemblages from Prague Castle. Památky archeologické I04: 183-230.

Blažková, G. 20I8. Frühneuzeitliche Keramik von der Prager Burg. In H. Stadler and L. Obojec (eds), Keramik zwischen Werbung, Propaganda und praktischem Gebrauch. Beiträge vom so. Internationalen Symposium Keramikforschung in Innsbruck 20I7, Nearchos 23, 253-27I. Innsbruck.

Blažková, G. 2019. Painted Pottery in Bohemia. Slipware of the I6th and the I7th Centuries. In G. Blažková and K. Matějková (eds), Europa Postmediaevalis 20I8. Post-medieval pottery between (its) borders, II5-I28. Oxford.

Blažková, G., Kloužková, A. and Kolářová, M. 202I. Distilation Ceramics from Prague Castle, Czech Republic. In G. Blažkova and K. Matějková (eds), Europa Postmediaevalis 2020. Post-medieval pottery in the spare time, 28I-296. Oxford.

Blažková, G. and Vepřeková, J. 20I5. Nálezy hmotné kultury z renesančních odpadních jímek z Pražského hradu Material Finds from the Renaissance Waste pits at Prague Castle. Castrum Pragense 13/I, Katalog. Prague.

Blažková, G. and Žegklitz, J. 2016. Současný stav poznání raně novověké keramiky v Praze. In I. Boháčová and M. Šmolíková (eds), Praha archeologická. Archaeologica Pragensia - Supplementum 3, I47-178. Prague.

Blažková, G., Jonášová, Š., Kavanová, M., Kloužková, A., Kohoutková, M., Matějková, K., Randáková, S., Skála, R., Svobodová, L., Vepřeková, J. and Zemenová, P. 20I6. Nálezy hmotné kultury z renesančních odpadních jímek z Pražského hradu - Material Finds from the Renaissance Waste pits at Prague Castle. Castrum Pragense I3/II, Studie. Prague. 
Bůžek, V., Král, P. and Vybíral, Z. 2007. Člověk českého raného novověku. In V. Bůžek and P. Král (eds), Člověk českého raného novověku, 9-53. Praha, Argo.

Cymbalak, T. and Matějková, K. 20I2. Zpracování nálezů ze dvou odpadních jímek a úskalí jejich interpretace - Analysis from two cesspits and problems with their interpretation. Staletá Praha 28(2): 4I-76.

Cymbalak, T., Matějková, K., Musílek, M. and Sawicki, J. 20ı9. Novoměstská odpadní jímka se souborem cínového zboží. Limity výpovědi jejího obsahu k poznávání uživatelů i hmotné kultury - A Newtown Cesspit with an Assemblage of Pewter Ware: Evidential Limits of its Content Regarding Material Culture and its Users. Staletá Praha 35(2): 28-67.

Čapek, L. and Militký, J. et al. 2016. Historická radnice v Českých Budějovicích ve svètle archeologických výzkumu a rozboru hmotných pramenů. Plzeň - České Budějovice.

Čapek, L. and Preusz, M. 2orga. Changes in Pottery Production, Distribution and Consumption in the Post-Medieval Period in South Bohemia. In G. Blažková and K. Matějková (eds) Europa Postmediaevalis 20I8. Post-medieval pottery between (its) borders, 35-52. Oxford.

Čapek, L. and Preusz, M. 20I9b. Středověké a novověké hrnčiřské pece v Čechách - kritické zhodnocení výpovědních možností studia - Mittelalterliche und neuzeitliche Töpferöfen in Böhmen - eine kritische Auswertung der Aussagemöglichkeiten von Studien. Archaeologia historica 44: 313-355. https://doi.org/IO.5817/AH2OI9-I-I4.

Čapek, L., Těsnohlídková, K., Slavíček, K., Všianský, D. and Pracný, P. 20I8. Technologie výroby a archeometrické studium strédověké keramiky. Plzeň - Brno.

Čiháková, J. and Müller, M. 20Iz. Hygienické zázemí koleje theatinů v Thunovské ulici na Malé Straně - Hygienic facilities of the Theatine College in Thunovská Street at Malá Strana. Staletá Praha 29(2): $120-184$.

Dohnal, M., Korený, R., Koucký, K., Procházka, L. and Šamata, J. 20oI. Obděnice, čp. 4 (okr. Př́bram). Dějiny usedlosti ve světle etnografických, písemných a paleozoologických pramenů - No. 4, Obděnice (Př́bram district) The history of a homestead in the light of ethnographic, archaeological, written and palaeozoological sources. Archeologie ve střednich Čechách 5: 72I-738.

Dohnal, M. and Koucký, K. 2000. Analýza části novověkých nálezů z archeologického výzkumu městské parcely v Sedlčanech (okr. Pŕíbram) - Analysis of part of the Early Modern finds from the archaeological investigation of urban plots in Sedlčany (Př́bram district). Archeologie ve střednich Cechách 4: 359-382.

Dohnal, M. and Vařeka, P. 2002. Novověké artefakty z bývalého kapucínského kláštera v areálu někdejších kasáren Jiř́iho z Poděbrad na náměstí Republiky v Praze I (zjištovací výzkum v letech 1998-I999) Early modern artefacts from the former capuchin monastery in the area of the former George of Poděbrady barracks on nám. Republiky in Prague I (Test trenching in 1998-1999). Archaeologica Pragensia 16: 25I-294.

Drnovský, P. 20I8. Hmotná kultura šlechtických sídel severovýchodních Čech. Každodennost ve středověku pohledem archeologie. Archeologické studie Univerzity Hradec Králové 3.

Enders, W. 1982. Straubinger Keramik um I60o - Der Fundkomplex "vorm obern Tor", Vorbericht I (Die Geschirrkeramik von Objekt 2). Jahresbericht des Historischen Vereins für Straubing und Umgebung 84: 15-52.

Enders, W. 1990. Straubinger Keramik um I600 - Der Fundkomplex "vorm obern tor", Vorbericht 6 (= Alburger Weg = "Arco-Komplex", Objekt 33). Jahresbericht des Historischen Vereins für Straubing und Umgebung 92: 35-8I. 
I34 Gabriela Blažková

Enders, W. 2005. Straubinger Renaissancekeramik. Straubing.

EP 20I9. Blažková, G. and Matějková, K. (eds), Europa Postmediaevalis 20I8. Post-medieval pottery between (its) borders. Oxford.

EP 2021. Blažková, G. and Matějková, K. (eds), Europa Postmediaevalis 2020. Post-medieval pottery in the spare time. Oxford.

Frolík, J., Žegklitz, J. and Boháčová, I. 1988. Kanovnická ulice (Canons’ street) No. 73. Castrum Pragense 1: 43-56.

Gaimster, D. R. M. 2006. The Historical Archaeology of Pottery Supply and Demand in the Lower Rhineland, $A D$ 1400-1800. Oxford, BAR International Series 1518, Studies in Contemporary and Historical Archaeology I.

Hazlbauer, Z. 1998. Krása stréedověkých kamen. Odraz náboženských ideji v českém uměleckém řemesle - Die Schönheit der mitteralterlichen Kachelöfen. Reflexion religiöser Ideen im böhmischen Kunstgewerbe. Praha.

Klápště, J. (ed.). 2002. Archeologie středověkého domu v Mostě (čp. 226) - The archaeology of a medieval House (No. 226) in Most. Mediaevalia Archaeologica 4. Praha - Most.

Kloužková, A., Kohoutková, M., Kolářová, M., Blažková, G., Šefců, R., Dvořáková, P. and Bajeux Kmoníčková, M. 2020. Muli-methodic/sal study of Early Modern Age archaeological glazed cereamics from Prague. Heritage Science 8. https://doi.org/I0.II86/s40494-020-00423-x.

Koula, J. 1917-1919. Co nám vyprávějí pražské střepy 17. století. Památky archeologické 29(1917): I2-16, I23-I29, I76-I84, 250-257; 30(I9I8): 27-34, IOI-IO8; 3I(I919): 25-27.

Krabath, S. 20I2. Die Entwicklung der Keramik im Freistaat Sachsen vom späten Mittelalter bis in das 19. Jahrhundert. Ein Überblick. In S. Krabath et al., Keramik in Mitteldeutschland - Stand der Forschung und Perspektiven. 4I. Internationales Hafnereisymposium des Arbeitskreises für Keramikforschung in Dresden, Deutschland, vom 2I. September bis 27. September 2008, 35-17I. Dresden, Veröffentlichungen des Landesamtes für Archäologie, Band 57.

Krajíc, R. 1998. Di̊m pasíre Prokopa v Táboře, Archeologický výzkum odpadni jímky v domě čp. 220. Písek.

Krajíc, R. 2007. Archaeology of the Post-Medieval period. The current state of research and research perspectives in South Bohemia. Studies in Post-Medieval Archaeology 2: 57-96.

Krajíc, R., Měřínský, Z. and Vařeka, P. 2017. Archaeology fot he I6th-2oth Century in the Czech Republic. Archaeologia historica 42: 367-399. https://doi.org/ı0.5817/AH2017-2-I.

Marešová, D. 200I. Záchranný archeologický výzkum v kapli Božího těla v Kutné Hoře. Př́íspěvek $\mathrm{k}$ dějinám kaple a pokus o vytvoření základního typáře keramických tříd vyskytujících se na Kutnohorsku ve 2. polovin I4. - počátku I6. století - Archäologische Rettungsuntersuchung in der Korpus-Christi-Kapelle in Kuttenberg. Beitrag zur Geschichte von der Kapelle und Versuche eine Bearbeitung der Mustersammlung von in Region Kuttenberg von der 2. Hä. des I4. Jh. bis dem Anfang des I6. Jh. vorkommende Keramikklassen. Archeologie ve střednich Čechách 5: 63I-648.

Matějková, K. 20I2. Soubor novověkých květníků z Vladštejnského casina u Jičína. Zprávy památkové péce 72(3): 159-165.

Matějková, K. 20I7. Keramikfunde aus der Latrine des Theatinerklosters auf der Kleinseite in Prag. In H. Stadler and L. Obojes (eds), Keramik zwischen Werbung, Propaganda und praktischem Gebrauch. Beiträge vom 50. Internationalen Symposium Keramikforschung in Innsbruck 2017. Nearcheos 23: 273-288.

Matějková, K. 2019. Bohemia Slipware from the Second Half of the 17th Century until the End of the I8th Century. In G. Blažková and K. Matějková (eds), Europa Postmediaevalis 20I8. Post-medieval pottery between (its) borders, I29-I40. Oxford. 
Current State of Knowledge of the Development of Early Modern Ceramics in the Czech Republic

Matějková, K. 202r. Forgotten Beauties. A Preliminary Study of Post-Medieval Flowerpots from the Czech Republic. In G. Blažková and K. Matějková (eds), Europa Postmediaevalis 2020. Post-medieval pottery in the spare time, 185-198. Oxford.

Matoušek, V. and Scheufler, V. 1983. Raně novověké berounské zboží ve světle archeologických výzkumů v Berouně. Archaeologia historica 8: 189-196.

Matoušek, V., Scheufler, V. and Štajnochr, V. 1985. Berounské majoliky - Majolika aus Beroun. Časopis Národního muzea - rada historická $A$ I54(2): 126-I39.

Mehler, N. 2013. Breaking New Ground: Historical Archaeology in Central Europe. In N. Mehler (ed.), Historical Archaeology in Central Europe, II-30. Rockville, Society for historical Archaeology.

Pajer, J. 1982. Hromadný nález ze začátku 17. století ve Strážnici. Strážnice.

Pajer, J. 1983. Počátky novověké keramiky ve Strážnici - Anfänge der neuzeitlichen Keramik in Strážnice. Strážnice.

Pajer, J. 200I. Novokřtènské fajánse ze Strachotina - Anabaptist faiences from Strachotín. Mikulov.

Pajer, J. 2006. Studie o novokŕtěncích. Strážnice.

Pajer, J. 2007. Archaeological excavation of Anabaptist ceramics in Moravia. Studies in Post-Medieval Archaeology 2: 227-250.

Petráň, J., Petráňová, L., Šimek, E. and Vogeltanz, J. 1995. Dějiny hmotné kultury II/I, Kultura každodenního života od I6. do I8. století. Praha.

Scheufler, V. 1972. Lidové hrnčirrstvi v českých zemích - Volkstümliche Töpferei in den böhmischen Ländern. Praha.

Schreg, R. 20I3. History, and Cultural Sciences in Germany: Some Reflections. In N. Mehler (ed.), Historical Archaeology in Central Europe, 3I-52. Rockville, Society for historical Archaeology.

Smetánka, Z. I968. Technologie výroby českých kachlů od počátku I4. do počátku I6. století - Die Technologie der Herstellung böhmischer Kacheln von Beginnen des I4. bis zum I6. Jahrhunderts. Památky archeologické 59: 543-578.

Smetánka, Z. 1969. K morfologii českých středověkých kachlů - Zur Morphologie der böhmischen mittelalterlichen Kacheln. Památky archeologické 60(I): 228-265.

Smetánka, Z. and Žegklitz, J. 1989. Historie a postmedievální archeologie. Český časopis historický 37: $728-738$.

Smetánka, Z. and Žegklitz, J. 1990. Post-mediaeval archaeology in Bohemia and its problems. Studies in Post-Medieval Archeology i: 7-22.

Stephan, H.-G. 1987. Die bemalte Irdenware der Renaissance in Mitteleuropa. Ausstrablungen und Verbindungen der Produktionszentren im gesamteuropäischen Rahmen. München.

Stephan, H.-G. 1992. Keramik der Renaissance im Oberweserraum und an der unteren Werra. Beiträge der Archäologie zur Erforschung der Sachkultur der frühen Neuzeit. Köln, Zeitschrift für Archäologie des Mittelalters, Beiheft 7.

Stephan, H.-G. 20I2. Das Pottland: Mittelalterliche und neuzeitliche Töpferei von landesgeschichtlicher Bedeutung und Keramik europäischem Rang in Niedersachsen. In Ch. Leiber et al., (eds), Aus dem Pottland in die Welt. Eine historische Töpferregion zwischen Weser und Leine, 9-71. Holzminden, Mitzkat.

Studies 1990. Z. Smetánka and J. Žeglitz (eds), Studies in Post-Medieval Archaeology I. Prague.

Studies 2007. J. Žeglitz (ed.), Studies in Post-Medieval Archaeology 2. Prague.

Studies 2009. J. Žeglitz (ed.), Studies in Post-Medieval Archaeology 3. Prague. 
I36 | Gabriela Blažková

Studies 20I2. J. Žeglitz (ed.), Studies in Post-Medieval Archaeology 4. Prague.

Šrejberová, J. (ed.). 20I8. Kachle a kachlová kamna: sborník př̀spèvkủ z mezinárodni konference k výstavě Svèt kachlových kamen - Ofenkacheln und Kachelöfen: Sammelband der Beiträge der internationalen Konferenz zur Ausstellung Die Welt der Kachelöfen. Most.

Štajnochr, V. 2004. Hrnce pro tepelné zpracování pokrmů. Studia funkcí novověké keramiky - Töpfe zur Hitzbehandlung von Speisen. Studien zur Funktion neuzeitlicher Keramik. Archeologie ve střednich Čechách 8: 80I-85I.

Štajnochr, V. 2005. Džbány. Studia funkcí novověké keramiky - Töpfe zur Hitzebehandlung von Speisen. Studien zu den Funktionen neuzeitlicher Keramik. Archeologie ve středních Čechách 9: 729-778.

Štajnochr, V. 2006. Mísy. Studia funkcí novověké keramiky - Schüsseln. Studien zu den Funktionen neuzeitlicher Keramik. Archeologie ve strédnich Čechách I0: 959-I046.

Štajnochr, V. 2007. Báně, transportní hrnce, spížní hrnce na ukládání tuků, konvice na náhražkovou kávu, hrnky a hrnečky. Studia funkcí novověké keramiky - Kuppelförmige Gefäße, Transporttöpfe, Speisekammertöpfe zur Fettaufbewahrung, Kannen für Ersatzkaffee, kleine Töpfe und Töpfchen. Studien zur Funktion neuzeitlicher Keramik. Archeologie ve střednich Čechách II: 739-790.

Štajnochr, V. 2008. Hrnce v technologii mléka, hrnce s výpustí, speciální smetanice, hrnčířské nádoby na lůj, pístové máselnice, syrnice. Studia funkce novověké keramiky - Töpfe in der Milchpdoduktion, Töpfe mit Ausguss, spezielle Sahngefäße, Töpfermelkgefäße, Buttergeffäße mit Kolben, Käsebilder. Studien zur Funtion neuzeitlicher Keramik. Archeologie ve střednich Čechách I2: 963-IOI2.

Vařeka, P. (ed.). 2013. Archeologie Modernity. Prístupy - metody - témata. Plzeň.

Vyšohlíd, M. 20II. Dvojdílné keramické dýmky 17. - 19. století z archeologických nálezů v Čechách Stub-stemmed clay pipes of the $17^{\text {th }}$ - I9th centuries from archaeological excavations in Bohemia. In J. Dano and N. Mihálová (eds), História výroby fajok a archeologické nálezy fajok na Slovensku, 7I-88. Levice.

Vyšohlíd, M. 20I4. Keramické dýmky ze zaniklého města v Praze-Libni - Clay tobacco pipes from the former Jewish town in Prague-Libeň. Archeologie ve střednich Čechách I8: 903-921.

Vyšohlíd, M. 20I5a. Hrnčířské předměstí v Berouně: První etapa archeologického výzkumu na parcele ppč. 296 - The potters' suburb of Beroun: The first stage of the archaeological excavation in land parcel No. 296. Archeologie ve střednich Čechách 19: 4II-430.

Vyšohlíd, M. 20Isb. Tváře pražských andílků. Archeologické nálezy dýmek se zajímaným výzdobným motivem - The faces of Prague cherubs. Archaeological finds of tobacco pipes with an interesting decorative motif. Archeologie ve stréednich Čechách 19: 839-845.

Witte, F. 20I4. Bemalte Teller im Garten. Eine Töpferei der Renaissance in Husum. Husum.

Žegklitz, J. 20II. Tertium "Ad lupum predicantem” - et ad Pastorem Bonum. Reformační zápasy na reliéfních českých gotických a renesančních kachlů - Tertium "Ad lupum predicantem" - et ad Pastorem Bonum. The Reformational struggle on Czech Gothic and renaissance stove tiles reliefs. Archeologické rozhledy 63: 644-655.

Žegklitz, J. 20I2. Grafické a další předlohy motivů na kachlích z českého prostředí. Renesanční kachle jako prostředek širrení idejí a kultury reformace - Prints and other artwork models for motifs on stove tiles in Bohemia. Renaissance stove tiles as an agent in the spread of Reformation ideas and culture. Archeologické rozhledy 64: 265-319.

Žegklitz, J. 20I3. Archaeology of the Modern Period in the Czech Territories: A long Tradition and Long Beginnings. In N. Mehler (ed.), Historical Archaeology in Central Europe, 53-68. Rockville, Society for historical Archaeology. 
Žegklitz, J. 2015. Zu den Anfängen der Malhornware in Böhmen. In S. Hesse and S. König (eds), Alteuropäische Forschungen 7: Von der Weser in die Welt. Festschrift für Hans-Georg Stephan zum 65. Geburtstag, 44I-453. Langenweissbach.

Žegklitz, J. 2019. Kachle z dílny hrnčíre Adama Špačka (I53I-I572) na Novém Městě pražském. Prague, Archeaologica Pragensia - Supplementum 5.

Žegklitz, J., Vitanovsky, M. and Zavřel, J. 2009. Soubor kachlových forem z pražské hrnčířské dílny Adama Špačka a její kachlová produkce v letech I53I-I572 - An assemblage of stove tile moulds from the Prague pottery workshop of Adam Špaček and its tile production in the years I53I-72. Archeologické rozhledy 6r: 427-466.

Žegklitz, J. and Zavřel, J. 1990. Geochemical and petrographical studies of the post-mediaeval pottery of the Prague and Beroun regions. On the questions of raw-material sources and provenance. Studies in Post-Medieval Archaeology I: 95-I26.

Okmhb.de 202I. Arbeitskeris Keramikforschung Electronic document: http://okmhb.de/arbeitskreiskeramikforschung-tagungsbaende/ (accessed March 24, 202I). 